\title{
CANDIDIASIS IN PEDIATRIC PATIENTS WITH CANCER INTERNED IN A UNIVERSITY HOSPITAL
}

\author{
Ana Maria Rabelo De Carvalho Parahym¹; Luciana Resende Bandeira De Melo²; \\ Vera Lúcia Lins De Morais ${ }^{3}$; Rejane Pereira Neves ${ }^{1 *}$
}

\begin{abstract}
${ }^{1}$ Departamento de Micologia, Centro de Ciências Biológicas, Universidade Federal de Pernambuco, Recife, PE, Brasil; ${ }^{2}$ Hospital Universitário Oswaldo Cruz, Pronto de Socorro Cardiológico, Recife, PE, Brasil; ${ }^{3}$ Hospital Universitário Oswaldo Cruz, Centro de Oncologia, Recife, PE, Brasil.
\end{abstract}

Submitted: January 02, 2008; Returned to authors for corrections: March 09, 2008; Approved: May 03, 2009.

\begin{abstract}
Fungi are common causes of infection in immunocompromised patients. Candida species are frequently involved in these cases. In order to investigate candidiasis in pediatric patients with cancer, clinical samples were collected from one hundred and twenty two patients interned in the Oswaldo Cruz University Hospital in Recife, Brazil. Yeasts were isolated from thirty-four clinical samples. The species isolated were: Candida albicans (fourteen isolates), C. parapsilosis (nine isolates), C. guilliermondii (two isolates) and C. tropicalis (two isolates). We found that candidemia was most frequent in patients with malignant hematology and that C. parapsilosis infections caused the highest mortality.
\end{abstract}

Key words: Candida spp.; fungi infection; candidaemia; pediatric patient; cancer.

\section{INTRODUCTION}

Fungal infection is an important cause of morbidity and mortality in immunocompromised pediatric cancer patients (19). The underlying disease, neutropenia and other risk factors, substantially alter the epidemiology of infection allowing the development of opportunistic infectious processes at some point during the immunosuppressive therapy $(5,24)$.

The risk of fungal infection in patients with cancer is also a function of the balance between the integrity of host defence mechanisms and the intensity of exposure to potentially pathogenic microorganisms in the host's environment (especially hospital pathogens) (26). Although anti-fungal drugs are administered at the start of chemotherapy this prophylaxis is often ineffective $(14,20)$. In addition, the use of wide spectrum antibiotics, treatment with corticosteroids and cytostatic substances, and invasive surgical procedures often predispose children to the development of fungal infections $(11,16)$.

The main opportunistic infectious agents are Candida species present in the gastrointestinal tract (12). Candida species produce infections that range from non-life-threatening muco-cutaneous illnesses to invasive processes that may involve virtually any organ in the body $(1,21)$. For example, epithelial cells of the buccal mucosa are very sensitive to chemotherapeutic drugs which may predispose the patient to candidiasis (15). Fungal septicemia is frequently associated with a primary buccal infections (7).

Since fungal infections are common in patients with cancer and lead to poor prognostic, the present study had the objective of evaluating the epidemiology of Candida infection in oncologic pediatric patients in the Oswaldo Cruz University Hospital / Pediatric Oncology Center, Recife, Brazil.

\section{MATERIALS AND METHODS}

This study was carried out between March 2006 and July 2007. The samples were collected according to the physicians request from 122 patients with cancer who were treated with radiotherapy and chemotherapy and that showed clinical manifestations of fungal infection such as fever, macular

*Corresponding Author. Mailing address: R. Major Armando de Souza Melo, 42/204, Boa Viagem, Recife, PE, Brasil. 51030-180. Fax: (+5581) 21268482. E-mail: aana_mrc@hotmail.com 
erythematous rash in the inguinal region, difficulty and burning when urinating, ulcerative lesions with white and cream deposits in the oral cavity. We collected blood samples from all neutropenic patients who had persistent fever and were not responding to antibiotics. All patients received prophylactic antifungal therapy with fluconazole $200 \mathrm{mg} /$ day for five to ten days.

All samples were collected over a period of three consecutive days. Venous blood samples were collected aseptically in central and peripheral vein by venipuncture into VACUTAINER $®$ tubes using EDTA anticoagulant. Oral samples were obtained by swabbing the palatal and buccal mucosa. Urine specimens were collected in aseptic tubes after the urinary catheter had been removed and samples taken from the inguinal region. All samples were processed immediately after collection by standard methods for mycological diagnosis (direct examination and isolation in culture) at the Medical Mycology Laboratory, Federal University of Pernambuco, Recife, Brazil.

The direct examination was performed on the fresh samples (without clarification and staining) or clarified with $20 \%$ potassium hydroxide solution when necessary. For isolation, spreading was performed on the surface of Sabouraud agar with $0.5 \mathrm{mg}$ of yeast extract/ $\mathrm{L}$ and $50 \mathrm{mg}$ chloranphenicol/L, and then incubated at between $30^{\circ} \mathrm{C}$ and $35^{\circ} \mathrm{C}$ in an aerobic atmosphere for 15 days. After isolation and culture purification, identification was achieved using recognized macroscopic, microscopic, and physiologic features according to the criteria described by Barnett et al. (4) and Hoog et al. (9) and VITEK 120 test methods.

\section{RESULTS}

Diagnostic identification was based on both the presence of yeast cells (and some times pseudohyphae and true hyphae) in direct examination (Fig. 1) and the isolation of the causal agent in pure culture. The isolates ferment and assimilate carbohydrates and assimilate ammonium sulfate, which distinguishes it from other members of the genus Candida.

Candidiasis occurred in 28 patients, 21 of these had candidaemia, five oral candidiasis and candidaemia, one urinary infection and candidaemia and one inguinal candidiasis. Yeast colonies were isolated in 27 samples from blood, five from oral cavity and one from urine and inguinal region. This analysis yielded a distribution of 14 instances of Candida albicans, nine of $C$. guilliermondii, nine of $C$. parapsilosis and two of $C$. tropicalis (Table 1). Death rates due to infection by these species were $50 \%, 11 \%, 56 \%$ and $50 \%$ respectively.

Systemic blood infection was the most prevalent fungal infection and of the 27 samples of blood positive for fungi 17 (63\%) came from patients with malignant hematology and 10 (37\%) from patients with solid tumors. Thus candidaemia was more common in patients with malignant hematology.

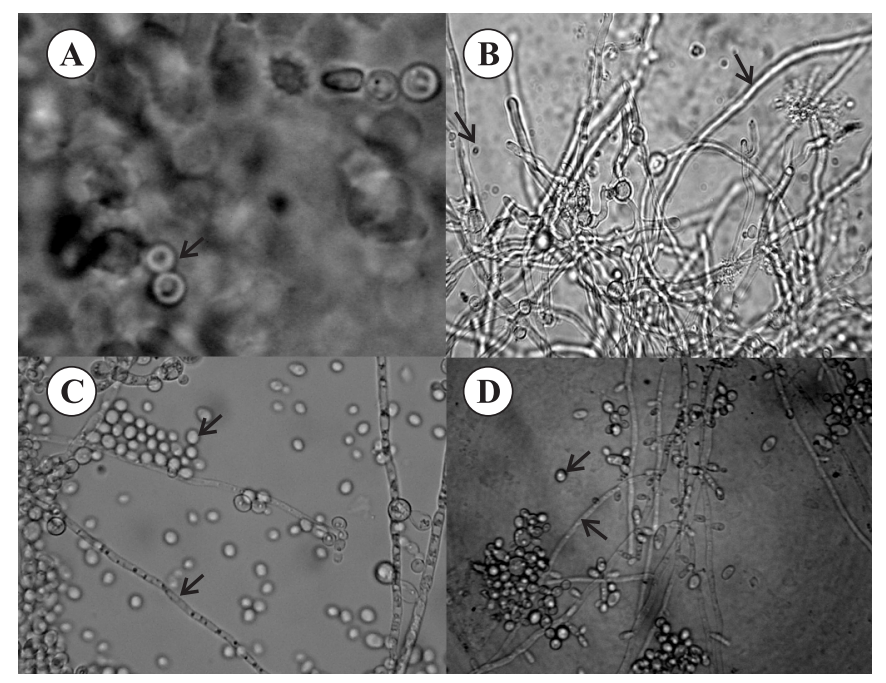

Figure 1. Direct examination revealed yeast cells in blood-1000x (A) hyphae hyaline and yeast cells in inguinal region (B), oral secretion (C) and urine (D) -400x.

Table 1. Yeast isolated from cultures in Oswaldo Cruz University Hospital/ Pediatric Oncology Center in the period of March of 2006 the July of 2007.

\begin{tabular}{lccc}
\hline Yeast species & Localization & $\begin{array}{c}\mathbf{N}^{\mathbf{0}} \text { of } \\
\text { isolates }\end{array}$ & $\begin{array}{c}\text { Total }^{\mathbf{0}} \\
\left(\% \text { of total no }^{\mathbf{o}}\right)\end{array}$ \\
\hline Candida albicans & Blood & 7 & $20.59 \%$ \\
& Oral cavity & 5 & $14.71 \%$ \\
& Inguinal region & 1 & $2.94 \%$ \\
& Urine & 1 & $2,94 \%$ \\
C. parapsilosis & Blood & 9 & $26,47 \%$ \\
C. guilliermondii & Blood & 9 & $26,47 \%$ \\
C. tropicalis & Blood & 2 & $5,88 \%$ \\
\hline Total & & 34 \\
\hline
\end{tabular}

\section{DISCUSSION}

Oral candidiasis represents a problem for children with cancer due to the possibility of a systemic infection that may be life threatening. However, it has been reported that the use of preventive therapy before the establishment of chemotherapy may decrease the incidence of oral candidiasis (22). In our patients, preventive therapy with oral fluconazole also reduced the incidence of oral candidiaisis.

About 10 to $15 \%$ of urinary tract hospital infections are due to Candida spp., and its prevalence is increasing $(3,27)$. Importantly, in all relevant studies candiduria was detected prior 
to development of candidemia indicating a probable ascending route of infection $(18,23,25)$. In our study the same Candida species was detected in the urine and blood of one patient indicating the occurrence of candiduria as possible route of systemic infection.

Although C. albicans remains the most common pathogen in oropharyngeal, urine and cutaneous candidiasis, non-albicans species are increasingly associated with invasive candidiasis (10). These epidemiologic changes are attributable to a combination of factors, such as the use of fluconazole prophylaxis, changes in patient demographics and underlying diseases, and use of therapeutic strategies that may pose unique risks (17).

For example, $C$. guilliermondii is rarely isolated in fungaemia cases but is emerging as a cause of candidaemia in cancer patients (6). This yeast was often isolated in our study with a high incidence in cancer patients. C. parapsilosis is the second most common species found in patients with candidaemia (8). The reasons for the rising incidence of $C$. parapsilosis candidaemia are not completely known, although venous catheters and parenteral nutrition have been recognized as specific risk factors and have a poor prognosis (2). In our study all patients with this infection were using venous catheters and parenteral nutrition. Possibly the large number of deaths caused by this infection occurred because of the constant use of such instruments that have become recurring sources of infection resulting in a poor prognosis for the patient. The presence of yeast in the blood may be associated with the use of venous catheters and, in many cases the same yeast species was isolated in blood culture and in the microbiological examination of the catheter (13).

Patients with cancer are commonly affected by fungal infections. However, in patients with malignant hematology these are more frequently due to the aggressive anti-neoplastic therapy (26). In our research we found the same result.

In conclusion, fungal bloodstream infections are most common in pediatric patients with cancer. $C$. albicans is the most common etiologic agent. C. guilliermondii and $C$. parapsilosis are more common in bloodstream infections in patients with cancer. $C$. parapsilosis causes greatest mortality in candidaemia episodes. C. guilliermondii fungaemia is rare but is frequently seen in cancer patients and candidaemia is most frequently observed in patients with malignant hematology.

\section{RESUMO}

\section{Candidíases em pacientes pediátricos com câncer internados em um hospital universitário}

Os fungos são causas comuns de infecções em pacientes imunocomprometidos e espécies de Candida são freqüentemente envolvidas nesses casos. A fim de investigar infecção fúngica em pacientes pediátricos com câncer, amostras clínicas foram coletadas de cento e vinte dois pacientes internados no Hospital Universitário Oswaldo Cruz em Recife, Brasil. Leveduras foram isoladas de trinta e quatro amostras clínicas. As leveduras isoladas foram: Candida albicans (catorze isolados), C. parapsilosis (nove isolados), C. guilliermondii (dois isolados) e C. tropicalis (dois isolados). Descobrimos que candidemia foi mais freqüente em doentes com hematologias malignas e que $C$. parapsilosis apresentou maior mortalidade.

Palavras chave: Candida spp., infecção fúngica, candidemia, paciente pediátrico, câncer.

\section{REFERENCES}

1. Alberth, M.; Majoros, L.; Kovalecz, G.; Borbás, E.; Szegedi, I.J.; Márton, I.; Kiss, C. (2006). Significance of oral Candida infections in children with câncer. Pathol. Oncol. Res., 12: 237-241.

2. Almirante, B.D.; Rodríguez, B.J.; Park, M.; Cuenca-Estrella, A.M.; Planes, M.; Almela, J.;. Mensa, J.; Sanchez, F.; Ayats, J.; Gimenez, M.; Pere Saballs, P.; Fridkin, S.K.; Morgan, J.; Rodriguez-Tudela, J.L.; Warnock, D.W.; Pahissa, A. (2005). Epidemiology and predictors of mortality in cases of Candida bloodstream infections: results from population-based surveillance, Barcelona, Spain, from 2002 to 2003. J. Clin. Microbiol. 43: 1829-1835.

3. Álvarez-Lerma, F.; Nolla-Salas, J.; León, C.; Palomar, M.; Jordá, R.; Carrasco, M.; Bobillo, F. (2003). Candiduria in critically ill patients admitted to intensive care medical units. Intensive Care. Med., 29: 1069-1076.

4. Barnett, J.A.; Paine, R.W.; Yarrow, D. (2000). Yeasts: Characteristics and Identification. CambridgeUniversity Press, Cambridge.

5. Binelli, C.A.; Moretti, M.L.; Assis, R.S.; Sauaia, N.; Menezes, P.R.; Ribeiro, E.; Geiger, D.C.P; Mikami, Y.; Miyaji, M.; Oliveira, M.S.; Barone, A.A.; Levin, A.S. (2006). Investigation of the possible association between nosocomial candiduria and candidaemia. Clin. Microbiol. Infec., 12: 538-543.

6. Castro, T.L.; Coutinho, H.D.M.; Gedeon, C.C.; Santos, J.M.; Santana, W.J.; Souza, L.B.S. (2006). Mecanismos de resistência da Candida Sp. Wwa antifúngicos. Infarma, 18: 9-10.

7. Childers, N.K.; Stinnett, E.A.; Wheeler, P.; Wright, J.T.; Castleberry, R.P.; Dasanayake, A.P. (1993). Oral complications in children with cancer. Oral Surg. Oral Med. Oral Pathol., 75: 41-47.

8. Clark, T.A.; Slavinski, S.A.; Morgan, J.; Lott, T.; Arthington-Skaggs, B.A.; Brandt, M.E.; Webb, R.M.; Currier, M.; Flowers, R.H.; Fridkin, S.K.; Hajjeh, R.A. (2004). Epidemiologic and molecular characterization of an outbreak of Candida parapsilosis bloodstream infections in a community hospital. J. Clin. Microbiol., 42: 4468-4472.

9. De Hoog, G.S.; Guarro, J.; Gene, J.; Figueras, M.J. (2000). Atlas of clinical fungi. The Netherlands, Centraalbureau voor Schimmelcultures, Universitat Rovira i Virgili, Utrecht/Réus.

10. Diekema, D.J.O.; Messer, S.A.O.; Brueggemann, A.B. (2002). Epidemiology of candidemia: 3-year results from the emerging infections and the epidemiology of Iowa organisms study. J. Clin. Microbiol., 40: 1298-1302.

11. Durango, H.; Hernández, M.; Zapata, C.; Sierra, M.; Peña, J.; Aristizábal, M.; Alzate, C.; López, P.; Posada, A. (2002). Colonización por especies de Candida en orofaringe y tracto gastrointestinal en niños. Infection, 63: 156-61.

12. Eggimann, P.; Garbino, J.; Pittet, D. (2003). Epidemiology of Candida species infections in critically ill non-immunosuppressed patients. Lancet. Infect. Dis., 3: 685-702. 
13. Fernandes, A.C.S.; Sousa Júnior, F.C.; de Oliveira, S.M.; Calich, L.; Milan, E.P. (2007). Prevalence of Candida species in umbilical catheters implanted in Newborns in Natal, Brazil. Braz. J. Microbiol., 38: 104-107.

14. Kuhn, D.M.; Ghannoum, M.A. (2004). Candida biofilms: antifungal resistance and emerging therapeutic options. Curr. Opin. Invest. Drugs., 5: 186-97.

15. Lockhart, P.B.; Sonis, S.T. (1979). Relationship of oral complications to peripheral blood leukocyte and platelet counts in patients receiving cancer chemothe-rapy. Oral. Surg. Oral. Med. Oral. Pathol., 48: 21-28.

16. Lopez Sastre, J.B.; Coto, C.D.; Fernandez, C.B. (2002). Neonatal sepsis of nosocomial origin: an epidemiological study from the Grupo de Hospitales Castrillo. J. Perinat. Med., 30: 149-157.

17. Marr, K.A. (2004). Invasive Candida infections: the changing epidemiology. Oncology (Williston Park, N.Y.), 18: 9-14.

18. Nucci, M.; Anaissie, E. (2001). Revisiting the source of candidaemia: skin or gut? Clin. Infect. Dis., 33: 1959-1967.

19. Oh, Y.W.; Effmann, E.L.; Godwin, J.D. (2000). Pulmonary infections in immunocompromised hosts: the importance of correlating the conventional radiologic appearance with the clinical setting. Radiology, 217: 647-56.
20. Paganini, H.; Rodriguez, B.T.; Santos, P.; Seu, S.; Rosanova, M.T. (2002). Risk factors for nosocomial candidaemia: a case-control study in children. J. Hosp. Infect., 50: 304-308.

21. Pappas,P.G.; Rex, J.H.; Sobel, J.D.; Filler, S.G.; Dismukes, W.E.; Walsh, T.J.; Edwards, J.E. (2004). Guidelines for Treatment of Candidiasis. Clin. Infec. Dis., 38: 161-89.

22. Rojas de Morales, T.; Zambrano, O.; Rivera, L.; Navas, R.; Chaparro, N.; Bernardonni, C.; Rivera, F.; Fonseca, N.; Tirado, D.M. (2001). Oral-disease prevention in children with cancer: testing preventive protocol effectiveness. Med. Oral., 6: 326-334.

23. Simpson, C.; Blitz, S.; Shafran, S.D. (2004).The effect of current management on morbidity and mortality in hospitalized adults with funguria. J. Infect., 49: 248-252.

24. Soni, N.; Wagstaff, A. (2005). Fungal infection. Curr. Anaesth. Crit. Care., 16: 231-241.

25. Talluri, G.; Marella, V.K.; Shirazian, D.; Wise, G.J. (1999). Immune response in patients with persistent candiduria and occult candidemia. J. Urol., 162: 1361-1364.

26. Vento, S.; Cainelli, F. Infections in patients with cancer undergoing chemotherapy: aetiology, prevention, and treatment (2003). Lancet. Oncol., 4: 595-604.

27. Weinberger, M.; Sweet, S.; Leibovici, L.; Pitlik, S.D.; Samra, Z.J. (2003). Correlation between candiduria and departmental antibiotic use. J. Hosp. infect., 53: 183-186. 